

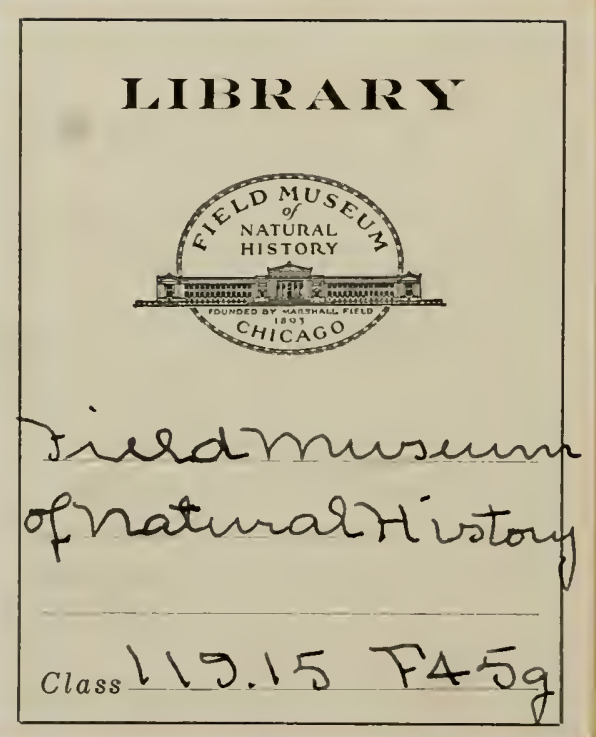


Field Museum of Natural History

Founded by Marshall Field, 1893

\section{Publication 254}

Geological Series

Vol. IV, No. 5

\section{CONTRIBUTIONS TO PALEONTOLOGY}

BY

SHarat Kumar Roy

Assistant Curator of Invertebrate Paleontology

Oliver Cummings Farrington

Curator, Department of Geology EDITOR

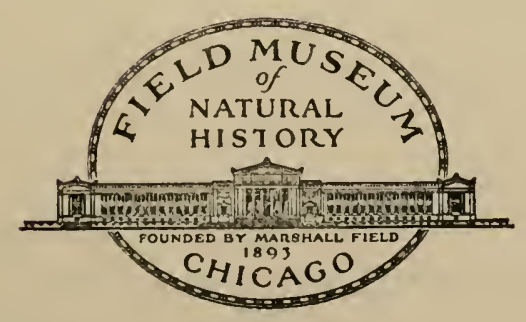

CHICAGO

February, 1929 
PRINTED IN THE: UNITED STATLS OF IAMERICA BY FIELD MUSELM PRESS 


\section{CONTRIBUTIONS TO PALEONTOLOGY}

BY

SHARAT KUMAR ROY

\section{INTRODUCTION}

This paper does not represent the paleontology of a definite horizon nor of a particular group of organisms. It deals with descriptions and discussions of a few Paleozoic fossils that have come to the author's notice, incidental to the general identification and cataloguing of portions of the Museum's paleontological collections. The features noted have been included here either because (a) they related to undescribed species or (b) were rare in American literature or (c) had interesting characters deserving of further comment. The specimens treated of in this paper range from Cambrian to Mississippian in age and have been derived from various sources. With the exception of two species of the genus Oracanthus, all are invertebrates.

The author wishes to express his gratitude to Dr. O. C. Farrington, Curator of Geology, for reading over the manuscript and giving many helpful suggestions during the course of preparation of this paper. Thanks are also due to Miss W. Goldring of the State Museum of New York, Albany, N. Y. for assistance rendered in finding literature for some of the South American species figured in Plates XXXVII and XXXVIII.

The drawings for this paper were made by Carl F. Gronemann, and the photographs by C. H. Carpenter. 



\section{Genus FAVOSITES Lamarck.}

Favosites limitaris Rominger. Plate XXXII, figs. I-4.

Favosites cariosus Davis, 1885. Kentucky Fossil Corals, Ky. Geol.

Survey, Pt. II, P1. 31, fig. 2; P1. 32, figs. I, 2 and 4.

The text or Part I of the Monograph of Kentucky Fossil Corals has never been published. In Part II, which is composed only of plates, Mr. Davis figures four specimens ${ }^{1}$ of $F$ avosites from the Lower Devonian of Louisville, Ky., under a new specific name, cariosus.

The Borden Collection, presented to Field Museum by Mrs. Geo. W. Robb, contains a number of specimens of this coral from the same locality as those figured by Davis, but they do not call for a new specific designation. On the contrary, they are identical with $F$. limitaris Rominger. They present, however, a different superficial appearance, especially in older specimens, because of the secondary alterations that have taken place in them since they were fossilized. These alterations are characterized by dissolution of some of the corallite walls (usually in longitudinal rows which tend to make the orifices appear continuous), by the narrowness of the corallite channels, due to excessive incrassation of their walls and by the gaining and lengthening of the mural pore channels. These features are best seen on the side of the corallum that was directly in contact with the rock formation and where the work of chemical erosion and deposition had probably once been active. The exposed side of the corallum, usually shows its original structure to be like that known in typical $F$. limitaris.

Horizon and locality:-Lower Devonian. Louisville, Ky.

Collector:-William W. Borden.

No. $\mathrm{P}_{21684}$ Field Museum.

\section{Genus EUCALYPTOCRINUS Goldfuss.}

EUCALYPTOCRINUS BORDENI sp. nov. Plate XXXII, figs. 5-6.

Only the dorsal cup is preserved. This is ovate in outline. The plates are very thick and are marked by rounded but mostly elongated nodes which tend to coalesce, forming ridges. These ridges run either crosswise, lengthwise or from the margins of the plates and meet at the center.

1 Favosites cariosus, Wm. J. Davis, op. cit. 


\section{Field Museum of Natural History-Geology, Vol. IV}

The facet for the reception of the column is moderately excavated and the basal plates are completely hidden by the column. Radials are of moderate size, hexagonal, the lower ends curving abruptly inward. First costals a little smaller than the radials, wider than long, quadrangular. Second costals a little larger than the first, hexagonal and bear the first distichals on their upper sloping sides and the interdistichals on the truncated upper end. Second distichals pentagonal, almost three times as small as the first and twice as large as the fixed palmars. Palmars, the smallest plates of the calyx, the lower two subtrigonal and the upper ones quadrangular. First interbrachials, decagonal, the largest plates of the dorsal cup, and larger than the two combined of the second row; the two latter have the same size and form, much longer than wide and in close contact laterally to their entire length and truncated at the top. Interdistichals have the same form as the combined interbrachials of the second row but are much narrower and rise a little distance beyond the top of the fixed palmars.

The specimens have some similarity with Eucalyptocrinus elrodi but the plates are much thicker and the ornamentation is decidedly different from any other described species of the genus. The specific . name is in honor of the collector, Wm. W. Borden.

Horizon and locality:-Niagaran, Louisville, Kentucky.

Collector:-William W. Borden.

No. P I9543 Field Museum.

\section{Genus ANCYROCRINUS Hall.}

Ancyrocrinus bulbosus Hall. Plate XXXIII, figs. I-Io.

This species, showing singular modifications in the distal growth of the stem ${ }^{1}$ of a certain unknown crinoid or crinoids, has been described by Hall in the $5_{5}$ th Annual Report, N. Y. State Cabinet, (I862) p. II8. In the same report (p. Irg) he describes another species, namely, Ancyrocrinus spinosus. Hall's reason for separating these specimens into two distinct species cannot be satisfactorily understood. It is doubtful if they can be called specifically different because of their differences in general form, as these crinoidal bodies show a wide range of variation in form, in the central ascending processes and in the number and arrangement of the lateral, hook-like projections.

1The original position of these bodies is still a matter of discussion but the balance of opinion is in favour of regarding them as the base serving as a balance for the coumn and calyx above. 
The Borden Collection, presented to the Museum by Mrs. Geo. W. Robb, contains over 300 specimens of these distal ends from the Hamilton of Clark Co., Indiana. A few of these are here figured (P1. XXXIII) in order to show the nature of their variability. Since no calyx has yet been found associated with these bodies to signify to what crinoid ${ }^{1}$ they belong and considering that they are but stem-branches or modified roots, and, as such, liable to variations, it is a very plausible supposition that they may all belong to the same species.

Horizon and locality:- - Hamilton beds (Middle Devonian), Clark Co., Indiana.

Collector:-Wm. W. Borden.

No. P I 9654 Field Museum.

Genus POTERIOCRINUS Miller.

Poteriocrinus robbi sp. nov. Plate XXXIV, figs. I-2.

Calyx depressed through external influence and cup-shaped in outline, slightly wider at the top than high. Infrabasal five, small, pentagonal. Basals five, the two on the anterior side hexagonal, the other three indistinct in outline, as wide as high and larger than any other plates of the calyx. Radials almost twice as wide as high, pentagonal. First costals about the size of the radial, quadrangular. Second costals a little smaller than the first, pentagonal and supporting the first divisions of the arms on their superior sloping sides. Radianal about the size of first costal, pentagonal. Anal plates somewhat blurred and their exact forms cannot be determined.

Arms long, slender, branching and made of wedge-shaped pieces. The point of bifurcation is variable. Some bifurcate on the 8 th piece after the first division, some on the $\mathrm{I}_{3}$ th or on the lower or higher levels. The bifurcation of the arms on the posterior side is at a lower level than on the anterior side. It cannot be seen very well on the specimen whether each and every bifurcated arm bifurcates again, but after the second bifurcation the branching becomes simpler. The arms crowd together at the top and bear small pinnules.

The specific name is in honor of Mrs. Geo. W. Robb, who presented the Borden collection to the Museum.

Horizon and locality:-Burlington group (Mississippian), Burlington, Iowa.

It has been suggested by Springer (Smithsonian Inst. Pub. 2440, p. ro) that they may belong to Arachnocrinus, which has a quadripartite canal similar to Ancyrocrinus. (See Pl. XXXIII, figs. $6 ; 7$ of this paper). 
Collector:-Wm. W. Borden.

No. P I986 I Field Museum.

\section{Genus MYALINA de Koninek, 1844.}

Myalina sappenfieldi sp. nov. Plate XXXV, figs. I-2.

The specimen is unusually large in size compared to any other known Mississippian form of the genus. It is an internal cast, part of the postero-ventral region having been broken off. Since the growth lines on the shell are not visible, its complete form cannot be reconstructed with exact accuracy.

In marginal outline it is obliquely subtrigonal, equivalve, strongly convex, its greatest convexity being the umbonal ridge. The ridge curves very gently toward the postero-ventral direction, diminishes gradually until it dies away at some distance from the ventral end, but bends rather abruptly toward the beak. Umbonal slope angular, slightly concave toward the postero-dorsal region. Anterior margin abruptly inflected, making an angle of $5 \mathrm{I}^{\circ}$ between the inturned portion on the anterior side and the adjacent portion of the valve. This inturned portion, that is, the space between the anterior margin of the valve and the line of inturning, gives the valves a somewhat flattened appearance on the anterior side. A portion of this flattened area commencing near the beak is noticeably concave inward; the other portion slopes outward, leaving a ridge somewhat diagonally between them. Hinge straight, shorter by $18 \mathrm{~mm}$. than the height of the shell measured at right angles to the hinge line. Beaks terminal, $12 \mathrm{~mm}$. apart, very prominent, extending $13 \mathrm{~mm}$. above the hinge, slightly incurved, gradually rounded. Cardinal area deeply furrowed and parallel to the hinge line. A few surface marks are obscurely visible on the right valve.

Measurements:- Height, $78 \mathrm{~mm}$. Length from the terminal point of the beak to as far as the specimen is preserved on the posteroventral end, I $39 \mathrm{~mm}$.

Horizon and locality: The specimen was found by $\mathrm{Mr}$. Gordon B. Sappenfield of New Salisbury, Indiana, in a quarry of Harrodsburg limestone, 6 feet under the surface. The quarry is about 4 miles west of Georgetown, Indiana, I $1 / 2$ miles east of the village of Byrneville, Indiana, and I 5 miles west of Louisville, Kentucky.

Remarks: The unusually large size of the specimen, its conspicuous umbonal ridge, the character of the anterior side, and the 
angle between the hinge line and the umbonal ridge are sufficiently distinguishing features to warrant a new specific name. I have much pleasure in naming this species in honor of $\mathrm{Mr}$. Gordon B. Sappenfield, who kindly sent the specimen to the Museum for examination.

The type specimen is now in the collection of the museum of New Salisbury High School, Georgetown, Indiana.

\section{Genus PALAEONEILO Hall.}

Palaeoneilo fieldi sp. nov. Plate XXXII, figs. 7-8.

There are two specimens of this species in the Museum collection, one of which is not complete. They are very similar to $P$.rhysa ${ }^{1}$ Clarke, but can be at once distinguished by their sculpture. The concentric lines are simple and not anastomose as in $P$. rhysa Clarke.

The specific name is in honor of Mr. Stanley Field.

Horizon and locality:-Devonian, Patacamaya, Bolivia, S. A. Collector:-H. W. Nichols.

No. P 2 1902 Field Museum.

\section{Genus MEGALOMUS Hall.}

Megalomus canadensis Hall. Plate XXXIV, figs. 3-4.

The effect of pressure is very markedly shown in this specimen. The umbones have been considerably depressed, leaving the space between them much wider than is seen in typical forms.

Horizon and locality:-Niagaran, Erie Co., Ohio.

No. P 21716 Field Museum.

\section{Genus PLATYCERAS Conrad.}

Platyceras daviesi sp. nov. Plate XXXVIII, fig. 7 .

This species is based on a single, incomplete, internal mold composed of two turns, or volutions, not tightly coiled. On the first part of the last turn there is a strong, transverse furrow, ventrally situated. Toward the mouth the shell enlarges in the form of a trumpet. The surface is covered with rather strong, concentric folds or undulations which undoubtedly would be found parallel to the mouth if the mold were unbroken. In the ornamentation of the shell the species resembles $P$. bistrami Knod, but the latter is a more closely coiled form and has two and a half turns. This

iFosseis devonianos do parana, 1913. Plate XI, figs. 5-7. 
specimen is not so loosely coiled as Platyceras sp. B. Kozlowski, but, except for the absence of undulations, strongly resembles Platyceras sp. A. Kozlowski.

(Faune Devonienne de Bolivie. Annales de Paleont., T. XII, p. 74, figs. 18,18 a.)

The specific name is in honor of the late Mr. D. C. Davies.

Horizon and locality:-Devonian, Patacamaya, Bolivia, S. A. Collector:-H. W. Nichols.

No. P 2 I gor Field Museum.

Genus HYOLITHES Eichwald.

Hyolithis welleri sp. nov. Plate XXXV, fig. 3 .

Form slender pyramidal. Length $\mathrm{I} 2 \mathrm{~mm}$., tapering to a point at the apex. Largest width at the aperture, $5 \mathrm{~mm}$. Cross section subtriangular. Dorsal side uneven; more convex than concave. Lateral edges acutely rounded. Surface of the dorsal side finely striated, both transversely and longitudinally. The transverse striae curve forward towards the larger extremity and pass upward at the lateral edges. They are not distributed at regular intervals and some are more conspicuous than others. The central longitudinal striation is much deeper than the others. It runs from one extremity to the other, dividing the dorsal side into two equal halves.

Remarks: There are four of these specimens (dorsal sides) in the museum collection, two of which are beautifully preserved. They agree in general form with $H$. americanus Billings, but the surface ornamentation, especially the character of the longitudinal striae, shows sufficient difference to indicate a new species. The specific name is in honor of the late Dr. Stuart Weller.

Horizon and locality:-Lower Cambrian. Conglomerate limestone on the east of the city of Troy, N. Y.

Collector:-S. K. Roy.

No. P 2 I 766 Field Museum.

Genus NAWNITES gen. nov.

The genus is based on a single specimen. It was found in the dark gray Ithaca sandstone beds (Middle Devonian) at Riverside quarry, Gilboa, Schoharie Co., N. Y. 
The exact nature of the specimen is not very well understood. Since it can be associated with worm-borings, trails, impressions or other obscure remains of unknown or little known animals, its place in systematic classification has to be necessarily vague. For the same reason and on account of insufficient material, a satisfactory general generic description also cannot be given. The accompanying discussion and description of the specimen under the name Narmites gilboensis, will perhaps prove to be adequate for the present.

Nawnites gilboensis gen. et sp. nov. Plate XXXVI, figs. I, la-lb.

The specimen has a serpentine form, is long and narrow. At first sight it appears to be a worm burrow filled up by the matrix of the rock in which it occurs, but closer examination reveals other significant characters that make such an assumption doubtful. At one end and at a little distance from the opposite end, where the body of the specimen has been removed, poorly defined markings (see figs. la-lb) somewhat suggestive of the creeping movement of mollusks can be observed. But the presence of a narrow, flat, threadlike substance of a much darker shade running in a zig-zag manner more or less medially throughout the entire length of the specimen, again suggests that it could be of some other nature. The thread-like substance suggests the existence of an alimentary canal, and although it is uncommon to find a soft-bodied organism so well preserved, one may consider it possible that the specimen is the actual remains of some form of an annelid. The zig-zag course of the thread-like substance may indicate the presence of an organ in which contraction took place after the death of the organism and the dark color may be due to the filling of such an organ with carbonaceous mud, such as is the usual food of annelids. In such an interpretation, the trail-like markings at either end previously referred to can be explained as impressions of the ventral side of the worm. An organism having transverse segmentation of ridges and furrows meeting at a median longitudinal depression on its ventral side will leave an impression of this nature. Yet the great length of the specimen throws doubt on the possibility of its being the actual remains of an annelid. It is not very likely that an annelid of such length existed in Middle Devonian time. To the writer's knowledge, there is no recorded species of the same age having the same size.

If the specimen is a buried mollusk track, the dark-colored, thread-like substance, before alluded to, may be accounted for as 
being the slimy material of the body of the animal left behind as it hitched its way along. However, the course of the trail is not so winding and tortuous (except at one end) as is usually seen in the trails made by gastropods, amphipods and other short invertebrates. It is more in accord with the worm-like trail made by elongated annelids. Furthermore, the markings in the trails of gastropods, as may often be seen on sandy beaches, are not similar to those of this specimen. The trails which gastropods leave in wet sand are bounded by lateral ridges and are marked transversely by ridges which bow forward in the direction in which the animals move. But the markings in the specimen under discussion, where they are exposed to view, have no lateral ridges. They show instead, a median, longitudinal ridge joined by transverse curved ridges and furrows coming from the lateral margins. In this, the specimen somewhat resembles the vermiform impression known as Nereites.

It is hoped that the discovery of more material of similar nature may throw further light on the true nature of this specimen.

The specimen was donated by Mr. Hugh Nawn and in his honor the generic name is proposed.

Measurements:-Length $3 \frac{3}{8}$ feet, I inch, $(95 \mathrm{~cm}$.) average width $\frac{9}{10}$ inch $(23 \mathrm{~mm}$.)

Horizon and locality:-Middle Devonian, Ithaca beds, Riverside quarry, Gilboa, Schoharie Co., N. Y.

No. P 2 r 897 Field Museum.

Wanneria walcottanus (Wanner). Plate XXXV, fig. 4.

Olenellus (Holmia) walcottanus (Wanner), rgor, Proc. Washington Acad. Sci., Vol. 3, pp. 267-269, P1. 3 I, figs. I, 2 ; P1. 32 figs. I-4. Wannera walcottanus (Wanner) rgro, Smithsonian Miscellaneous Coll. Vol. 53, No. 6, pp. 302-04, Pl. 30, figs. $\mathrm{I}-12$; Pl. 3 I, figs. I2-I 3 .

The specimen is a pleural lobe of a thoracic segment. I have provisionally identified it with $W$. walcottanus (Wanner) chiefly on the evidence of similar surface ornamentation, although I have not been able to find any statement to the effect that such surface ornamentation is characteristic of the species.

Horizon and locality:-Lower Cambrian. Conglomerate limestone on the east of the city of Troy, N. Y.

Collector:-S. K. Roy.

No. P 2 I77 Field Museum. 
Genus CRYPTONYMUS Eichwald, 1840.

CRyptonymus variolaris (Brong.) Plate XXXV, fig. 5.

(Known as the "Strawberryheaded Trilobite").

Calymmene variolaris Brong., I822, Crust. Foss., p. I4, Plate I, fig. 3-b not 3-a. Parkinson, Org. Rem. Vol. 3, Plate 17 , fig. I6. (Not named.)

Calymmene variolaris Murch., Sil. Syst. 1839, p. 655, Plate I4, fig. I.

Cybele variolaris Salter, June I 848, Mem. Geol. Surv., Vol. 2, Plate I, p. 344. Hetcher, 1850, Quar. Jour. Geol. Soc., Vol. 6, p. 403, Plate 32, figs. 6-10.

Zethus variolaris McCoy, $\mathrm{x}_{51} \mathrm{I}, \mathrm{Pal}$. Foss. Woodw. Mus., p. 157.

Encrimurus variolaris Salter, 1853 , Mem. Geol. Surv., Dec. 7 th, p. 7 ,

Plate 4, figs. I3-I.

Cryptonymus variolaris Vodges, Mong. genera Zethus etc. p. $2 \mathrm{I}$, Plate $x$, figs. 6-10; Plate 3, figs. I3-14.

1907. Trans. San Diego Soc. Nat. Hist. Vol. x, No. 2, Plate 3, p. 74, figs. I-10.

Cephalon subtriangular in outline. Glabella sub-pyriform, prominent, overhanging; almost twice as broad in front as at the occipital furrow. Lateral glabella furrows not distinguishable except the third one at the left which is also more or less indistinct, being very much like the depression between the rows of tubercles. Fixed cheek convex, triangular in outline, the one at the right somewhat crushed and not possessing the original form and outline. Eyes indistinct; noticeable only as an irregular, crescent-shaped depression, surrounded by tubercles. Genal angle somewhat rounded, with prominent tubercles at the extremity. The entire surface of the glabella and fixed cheeks, with the exception of the occipital ring and posterior marginal border, is covered with numerous rounded tubercles of unequal size.

The thorax has eleven segments. The axis is convex much narrower than the pleural lobes. The axial segments bend upward at the middle; the pleural lobes are flattened toward the axis, but bend abruptly downward from the middle toward the outer side. Surface of the thorax granulated, but this cannot be seen without the aid of a lens.

Pygidium subtriangular in outline, wider than long. Axis convex and divided into ten segments, each of which bears one or two tubercles. There are seven pleura on each side, although not all of those 
on the right side are distinct in the specimen. They bend outward and gradually curve backward. Surface of pleura same as that of the thorax.

Length $34 \mathrm{~mm}$., width $19 \mathrm{~mm}$. Both measurements are taken at the center of the specimen, lengthwise and crosswise.

Remarks: The specimen is from the Borden collection and is well preserved. The left fixed cheek and the left pleural lobes of the thorax are somewhat crushed and crumpled. The articulating half ring of the pygidium appears to have slipped over the last two axial segments of the thorax, covering them completely.

The specimen answers the description of $C$. variolaris (Brong.) except that the axis of the thorax does not show gradual tapering; the width from the first to the ninth segment is the same. The last two segments are hidden under the pygidium and are not visible.

Horizon and locality: Wenlock shale (Niagaran), Dudley, England.

Collector:-Wm. W. Borden.

No. P 2 I55 I Field Museum.

Nrobe? huberi sp. nov. Plate XXXV,

This is the first and only trilobite ever found associated with the graptolites in the Normanskill shale (Ordovician) at the railroad cut near Stuyvesant R. R. Station, N. Y. Unfortunately the specimen is poorly preserved and incomplete. It consists only of part of the thorax and the pygidium.

The thorax as far as preserved has six segments, not all of which are distinct. Axial lobe depressed convex, very wide $(3.5 \mathrm{~mm}$.), little less than half of the total width at the front.

Pygidium rounded in outline, with a sloping convex border (2 $\mathrm{mm}$. wide). Axial lobe wide at the anterior portion; tapers gradually but does not cross the border. Axial rings and pleural segments obscurely defined.

Remarks: In the absence of more adequate material, the generic reference is of course doubtful. It probably represents the genus Niobe and is closely allied to $N$. morrisi Billings and $N$. lineolata Raymond, but it differs from both in the greater width of the axial lobe of the thorax and the anterior portion of the pygidium. It also lacks the ornamental surfacial lines strikingly characteristic of $N$. morrisi (Billings) and N. lineolata Raymond. 
It is significant to note that the affinity of this specimen is with the Newfoundland trilobites and not with those of Virginia and Tennessee. But the evidence, based on a single, incomplete and poorly preserved specimen, seems quite inadequate for any stratigraphical reference.

I wish to express my gratitude to Prof. Percy E. Raymond of Harvard University and Dr. Rudolph Ruedemann of the State Museum of New York for their suggestions as to the identity of the specimen. The specific name is associated with Master Ross Huber, a young lad who helped me considerably in the field during the summer of 1926 .

Measurements: Length, from the tip of the pygidium to as far as the specimen is preserved, Io $\mathrm{mm}$. Width at the widest part of the thorax, $8 \frac{1}{2} \mathrm{~mm}$.

Horizon and locality: Normanskill shale (Middle Ordovician), near Stuyvesant R. R. Station, N. Y.

Collector:-S. K. Roy.

No. P 2 I 775 Field Museum.

\section{Genus CALMONIA Clarke.}

Calmonia? sp. Plate XXXVIII, figs. 6, 8.

(Ref. Clarke, J. M.-Fosseis Devonianos do Parana, I9r3, p. I I9-3I.)

Horizon and locality: Devonian, Patacamaya, Bolivia, S. A.

Collector:-H. W. Nichols.

No. P 2 I 899 Field Museum.

\section{Genus CRYPHAEUS Green.}

Cryphaeus australis Clarke. Plate XXXVII, figs. I-6.

1892. Cryphaeus giganteus Ulrich. Paleoz. Verst. aus Bolivien. (Neues jahrb. f. Min. etc., Beil.-Bd. VIII, p. I4, Plate I, figs. 6, 7 et 8 (?).)

1907. Cryphaeus giganteus Ulrich. Courty, Expl. géol. dans l'Amér. du S. (Miss. sc. G. de Créqui-Montfort, Paris, p. 50, Plate VII, figs. I, 2, 7, 8 et 10.)

I908. Cryphaeus giganteus Ulrich. Knod, Dev. Faunen Boliviens, p. 50r, Plate XXI, fig. 2. 
2 I 4 Field Museum of Natural History-Geology, Vol. IV

19r3. Cryphaeus australis Clarke. Fosseis Dev. do Paraná (Monogr. Serv. Geol. e Min. do Brasil, Vol, I, p. Io8 a, Plate III, figs. 7-I 4 and Plate IV, figs $1-5$.)

19r3. Cryphaeus sp. A. Kozlowski, Foss. Dév. de Paraná (Annales de Paleont., T. VIII, p. I5, figs. 5-5a).

1923. Cryphaeus australis Clarke. Kozlowski, Faune Dévonienne de Bolivie (Annales de Paléont., T. XII, pp. 4I-43, Plate III, figs. I-18).

Cryphaeus nicholsi sp. nov. Plate XXXVII, figs. 6-7.

Pygidium only. The species is very similar to $C$. australis Clarke, but differs in the character of its axial lobe. The axis is more gently convex and unlike $C$. australis it is much wider at the anterior portion and tapers more rapidly posteriorly.

The specific name is in honor of Mr. H. W. Nichols.

Horizon and locality:- Devonian, Patacamaya, Bolivia, S. A.

Collector:-H. W. Nichols.

No. P 2 I906 Field Museum.

Genus PHACOPS Emmrich.

Phacops Salteri Kozlowski. Plate XXXVIII, figs. $6 m, 10$

186x. Phacops latifrons Bronn. Salter, on the Fossils from the High Andes (Quart. Jour. Geol. Soc., London, Vol. XVIII, p. 65 , Plate IV, fig. 8).

1892. Phacops sp. Ulrich, Palaeoz. Verst. aus Bolivien, p. 22.

1908. Phacops sp. Knod, Dev. Faunen Boliviens, p. 501.

19I2. Phacops rana Green Groth, Bull. Soc. géol. de France, p. 607, Plate XIX, figs. 2 et 2 a.

1923. Phacops salteri Kozlowski, Faune Dévonienne de Bolivie (Annales de Paléont., T. XII, pp. 54-58, Plate VI, figs. I-6.)

\section{Sub-genus PHACOPINA Clarke.}

Phacopina Devonica (Ulrich). Plate XXXVIII, figs. I-5.

I892. Acaste devonica Ulrich, Palaeoz. Verst. aus Bolivien, p. 2 I, Plate I, figs. $14 \mathrm{a}, \mathrm{x} 4 \mathrm{~b}$ et $\mathrm{I} 5$. 
1907. Acaste devonica Ulrich in Courty, Expl. géol. en Amérique du Sud (Miss. scient. de G. de Créqui-Montfort, etc., Paris, Plate V, figs. 2,4 et 6.)

1923. Phacopina devonica Ulrich sp. in Kozlowski, Faune Dévonienne de Bolivie (Annales de Paléon., T. XII, pp. 49-5 r, Plate IV, figs. 7-14.)

\section{Genus ORACANTHUS Agassiz.}

Oracanthus vetustus Leidy. Plate XXXIX, figs. I-3; Plate XL, fig. 5.

This specimen from the Kinderhook group (Mississippian) is now on exhibition in the Walker Museum, University of Chicago. It was described by Newberry and was regarded to be specifically identical with Oracanthus vetustus ${ }^{1}$ (from the St. Louis limestone), figured by St. John and Worthen, who in turn regarded their specimen as the same as Leidy's type of Oracanthus vetustus ${ }^{2}$.

Newberry's description was found in his nearly complete MS. (I890-9I)relating to fossil fishes. In 1897 the MS. was edited by Bashford Dean and published in the Transactions of the New York Academy of Sciences ${ }^{3}$.

Newberry's description is as follows: "A spine of Oracanthus has recently been sent to me for examination by Mr. William F. E. Gurley, of Danville, Ill., which throws a flood of light on the structure of the spines of this genus and shows that we have had a very imperfect idea of their real nature. It is practically complete, only a small portion of the tip being wanting, and it shows what has been before unknown, the entire base of the spine which was buried in the integument. This is nearly as long as the exposed portion and is an elongated arch or half tube of bone which must have served as a firm support to resist all strains upon the spine from the front backward. The ornamented portion is below thickly crowded with relatively large tubercles which are beautifully sculptured ${ }^{4}$ and are, toward the front edge, arranged in curved lines parallel with that edge. Above, they are more sparsely set and, as so often seen in the genus, are arranged in oblique lines passing downward from

1Geol. Surv. Ill. vol. VII, p. 255, Pl. XXIV, figs. 2a-2d, I883.

${ }^{2}$ Proc. Phil. Acad. Nat. Sci., vol. VII, p. 414, I854-55. Jour. Acad. Nat. Sci. Phil., vol. III, Ser. 2, p. 161, P1. 16. figs. 1-3.

${ }^{3}$ Trans. N. Y. Acad. Sci., vol. XVI, pp. 285-288, Pl. XXII, fig. 3 (Oct. 1896 Dec. '97).

These tubercles are irregularly conical and are radiately sculptured, (see P1. XXXIX, fig. 2 of this paper). 
the front edge, then running transversely and again curving downward. Mr. Gurley's splendid spine is from the Kinderhook group. It is quite symmetrical, was unquestionably set on the middle line of the back and has not been much compressed.

The exposed portion is seven inches in vertical height and was once perhaps half an inch higher. The base is ten inches long, measured from front to rear, and beneath the ornamented portion shows a smooth and slightly incurved band which is so frequently seen in spines of Oracanthus which show the base. The shortness of this buried portion has been a puzzle, since it seemed to prove that the spines were set in the integument of the surface at a very shallow depth and therefore could have had little firmness. But the specimen now before us shows that, on the contrary, by the anterior projection ${ }^{1}$ of the base, the spine was prepared to endure a greater strain coming from the front than any other of which we have knowledge."

Notwithstanding the discovery of a number of specimens of Oracanthus since that genus was first instituted by Agassiz, ${ }^{2}$ our knowledge of the nature of these singular spines as well as of the spines of many other genera of Icthyodorulites is by no means complete. The protean forms of the spines of Oracanthus, their extremely variable size and the different styles of ornamentation of the exserted portions, have suggested to Davis ${ }^{3}$ that only a limited number of these spines were dorsal and that others were set on different parts of the body, after the manner of the spines of Climatius. An excellent example of this sort of dispersal of spines may be seen in the restored figure of Gyracanthides murrayi ${ }^{4}$ Wdwd. (P1. XXXIX, fig. 6). Assuming that the spines of Oracanthus were dispersed somewhat as in Gyracanthides or Climatius, it may be said that their diversity in form, size or style of ornamentation does not necessarily make them specifically different, since the spines of the various parts of the body of the same individual often do vary in form, size and pustulation. But, when specimens are found to have identical forms but have differences either in the character of the tubercles or in the style of tuberculation, it is reasonable to suppose that they are counterparts of specifically different individuals,

\footnotetext{
1The statement is erroneous. It should be "posterior" projection instead of "anterior."

${ }^{2}$ Recherches sur les Poissons Fossiles, vol. III, p. I3, I 833-43.

${ }^{3}$ Trans. Roy. Dub. Soc. Vol. I, ser. II, pp. 525-533, I883.

${ }^{4}$ Mem. Nat. Mus. Melbourne, No. I, text fig. I, 1906.
} 
since it is not likely that the same species will bear similar organs with unlike tubercles or unlike modes of arrangement of the tubercles.

We are, however, not familiar with the systematic allocation of the spines in the body of Oracanthus nor do we know the number of spines with their characteristic features that each individual possessed. Laboring under this difficulty the problem of specific differentiation becomes an extremely puzzling one. Doubtless, many specimens that have been specifically separated are not really different and vice versa.

A comparative study of the three specimens (those of Leidy, of St. John and Worthen and of Newberry) at once shows that the first two specimens are not symmetrical, at least so far as the tuberculose ornamentation is concerned, as they are both characterized by having marked differences in the arrangement of the tubercles on opposite sides, right and left (P1. XXXIX, figs. 4, 5). On the right side of Leidy's specimen, Leidy states that "the tubercles are arranged in rows, irregularly longitudinal, and irregularly oblique in the transverse direction." As a matter of fact, there is hardly any definite arrangement. The tubercles appear to be scattered in an indiscriminate manner. They are separate and seldom coalesce. On the left side he states that "they are arranged more regularly in longitudinal rows, and they evince a tendency to become confluent in short, transverse rows, which pursue an irregular waving course across the ray." St. John and Worthen's specimen has somewhat similar ornamentation on the respective sides but is by no means identical with Leidy's specimen. Newberry's specimen (PI. XXXIX, fig. I), however, does not show the marked differences in the arrangement of the tubercles on the right and left sides which have been noted in the other two specimens. The ornamentation on the two sides is quite similar if not identical. This fact of being symmetrical, both in form and ornamentation, is noteworthy, as it has an important bearing as to the relative position of the two asymmetrical specimens before alluded to. Not having found any spine of Oracanthus that showed the absolute symmetry required of dorsal spines, St. John and Worthen say "It may be well questioned whether these spines occupied a dorsal rather than a lateral position on the body of the fish. Thin flanks, instead of presenting that absolute symmetry characteristic of dorsal rays, at least so far as related to the tuberculose ornamentation, show marked asymmetrical features which may be more in accord with the latter interpre- 
tation of their relative position, or in pairs at the lateral line. We are, however, not sufficiently familiar with the species of the genus to be able to decide to what extent this asymmetrical character may be relied upon or whether it is persistent alike in all representatives of the genus."

Since the writer has had the opportunity of examining Newberry's specimen and also another specimen from the same horizon (Kinderhook) as described elsewhere in this paper (pp. 2 I 8-20), he is able to state that both of them are symmetrical in form as well as in ornamentation. This should dispel all uncertainty as to whether an asymmetrical character of the spines of Oracanthus is persistent alike in all representatives of the genus. It also at once confirms the view that only the spines that bear absolute symmetry occupied a dorsal position and that the others (including those that are thought to have symmetrical forms but asymmetrical ornamentation) occupied a lateral or other position on the body of Oracanthus. Since both Leidy's and St. John and Worthen's specimens are incomplete, it is not definitely known whether they were symmetri$\mathrm{cal}$ even in form. So far as they are preserved their form appears to be symmetrical..

Whether all three specimens here discussed belong to the same species or not cannot be said. They come from different horizons, vary in form and considerably in tuberculose ornamentation, yet there is no positive proof that they represent distinct species. As has been said before, their variations in form, size or style of ornamentation do not necessarily make them specifically different, as they might have easily occupied various positions on the body of the same individual. Without more knowledge of the systematic allocation of these spines and their individual characteristics, the difficulty of their specific separation cannot easily be disposed of. It is only when specimens are found to possess identical forms having differences in the character of tubercles or in the style of tuberculation that they may be interpreted to be the counterparts of specifically different individuals.

The writer here wishes to express his gratitude to Prof. A. S. Romer of the University of Chicago for making the Newberry specimen (No. 6244 University of Chicago) available for study.

Oracanthus farringtoni sp. nov. Plate XL, figs. I-4.

This is a gracefully arched, large, symmetrical and well-preserved but incomplete dorsal spine. The apex and part of the base, includ- 
ing the long, posterior, basal projection are wanting. The general outline is subtriangular with a backward curve. The spine tapers rapidly (in the original form it doubtless terminated in an acute apex) and it is very much compressed laterally. It is black in color, tinged with dark brown and is heavy, bony and densely fibrous. The anterior convex margin is more acutely rounded than the posterior concave margin. Both margins show signs of being studded with at least one row of tubercles, possibly with two rows on the anterior margin, which is a trifle wider. The sides of the spine are gently convex, forming in cross section a somewhat laterally compressed ellipse. (P1. XL, figs. 2, 3) The surfaces of the sides are studded with tubercles of variable shape and size and between the tubercles are marked with irregular, longitudinal costae. In general, the tubercles are imperfectly rounded, but near the posterior margin they tend to elongate. The surface of the tubercles, with the exception of their apices, which are smooth or inconspicuously pitted, has a wrinkled appearance. (P1. XL, fig. 4) In this respect the tubercles differ in a marked degree from the radiately sculptured tubercles of $O$. vetustus (P1. XL, figs. 4, 5) and as well as from those of other species of Oracanthus described by various authors. The arrangement of the tubercles is similar on both sides, right and left. They are disposed in longitudinal rows near the posterior margin, but in general they evince a tendency to coalesce in transverse rows which follow an irregular, waving course across the entire breadth of the spine.

The thickness of the spine is greatest near the base $(30 \mathrm{~mm}$.) just above the inserted portion, then it gradually thins out until it reaches the apex, where it is thinnest (I I mm,). The broken base shows a large internal cavity and thin walls enclosing it. The cavity, however, does not extend close to either margin of the spine (it extends farther toward the posterior than toward the anterior margin) nor does it reach the apex, as may be seen in the cross section. (P1. XL, figs. 2, 3)

Remarks: This spine unquestionably occupied a dorsal position. This can be inferred from its absolute symmetry, both in form and tuberculose ornamentation. Its large size, solid, bony apex and margins and the long, posterior basal projection, preparing it to endure greater strain coming from the front, are evidences in favor of its being an independent defensive weapon rather than a dorsal fin spine. 
220 Field Museum of Natural History-Geology, Vol. IV.

The specimen resembles $O$. vetustus ${ }^{1}$, described by Newberry, in form and in general style of ornamentation, but it differs from the latter by its larger size, in being less compressed laterally and by having less pronounced longitudinal rows of tubercles near the posterior margin. It also differs from Newberry's specimen in the character of its tubercles. In the Field Museum specimen the tubercles are not radiately sculptured (PI. XI., fig. 4), while those of Newberry's specimen (Pl. XL, fig. 5) are distinctly so. This difference in the character of the tubercles readily separates the two specimens into two distinct species.

I have much pleasure in naming this species in honor of $\mathrm{Dr}$. Oliver C. Farrington.

Measurements:- In its present condition the exserted portion (vertical height) is about $19 \mathrm{r} \mathrm{mm}$. ( 7.6 inches).

Horizon and locality:-Kinderhook (Mississippian), Le Grand, Iowa.

No. P 2 I 702 Field Museum.

1Transactions of the New York Academy of Sciences, Vol. XVI, pp. 285-288, Pl. XXII, fig. 3, Oct. 1896 - Dec. 1897. 


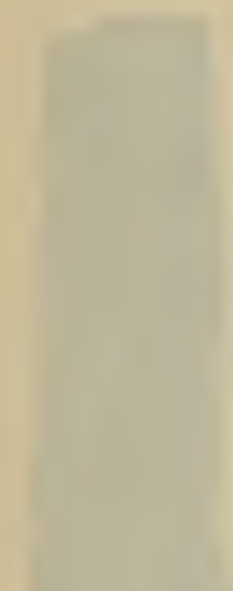

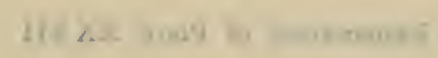

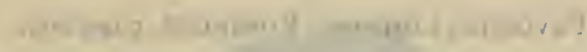

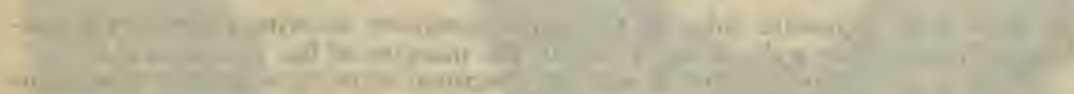

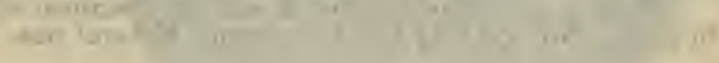

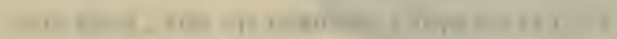

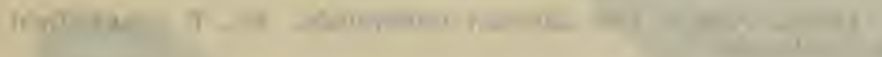

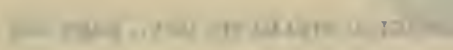

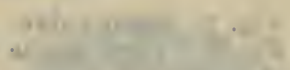

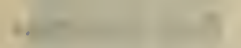

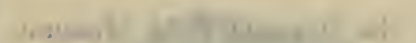

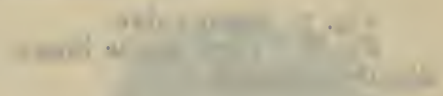




\section{Explanation of Plate XXXII}

FAvosites limitaris ROMINGer, page 203.

Figs. I, 2. Opposite sides of the same specimen showing secondary alterations in the corallite walls in fig. 2 and in the margins of fig. 1. Natural size.

Figs. 3,4 . Opposite sides of another specimen showing secondary alterations in parts. No. P 2 I684 Field Museum. Natural size.

EUCALYPTOCRINUS BORDENI sp. nOv., page 203.

Figs. 5, 6. Dorsal cups of two different individuals. No. P 19543 Field Museum. Slightly enlarged.

PALAEONeILO Fieldi sp. nov., page 207.

Fig. 7. Right valve.

Fig. 8. View of the hinge. No. P 21902 Field Museum. Both specimens slightly enlarged. 

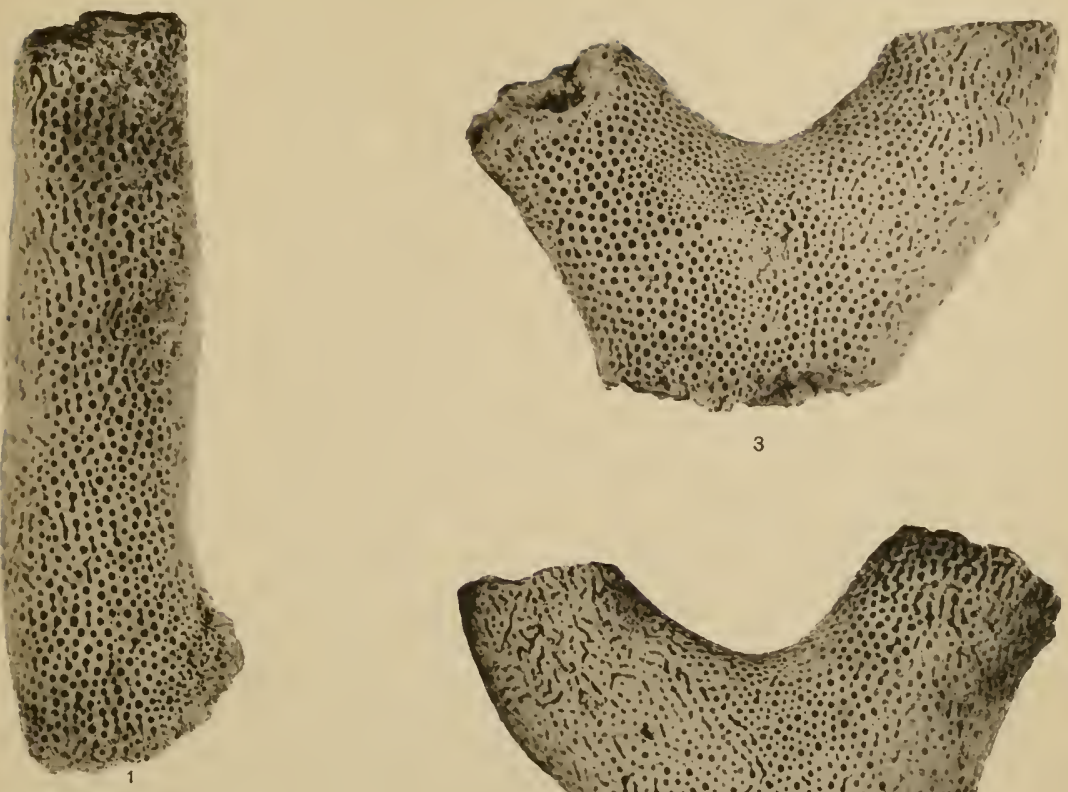

3
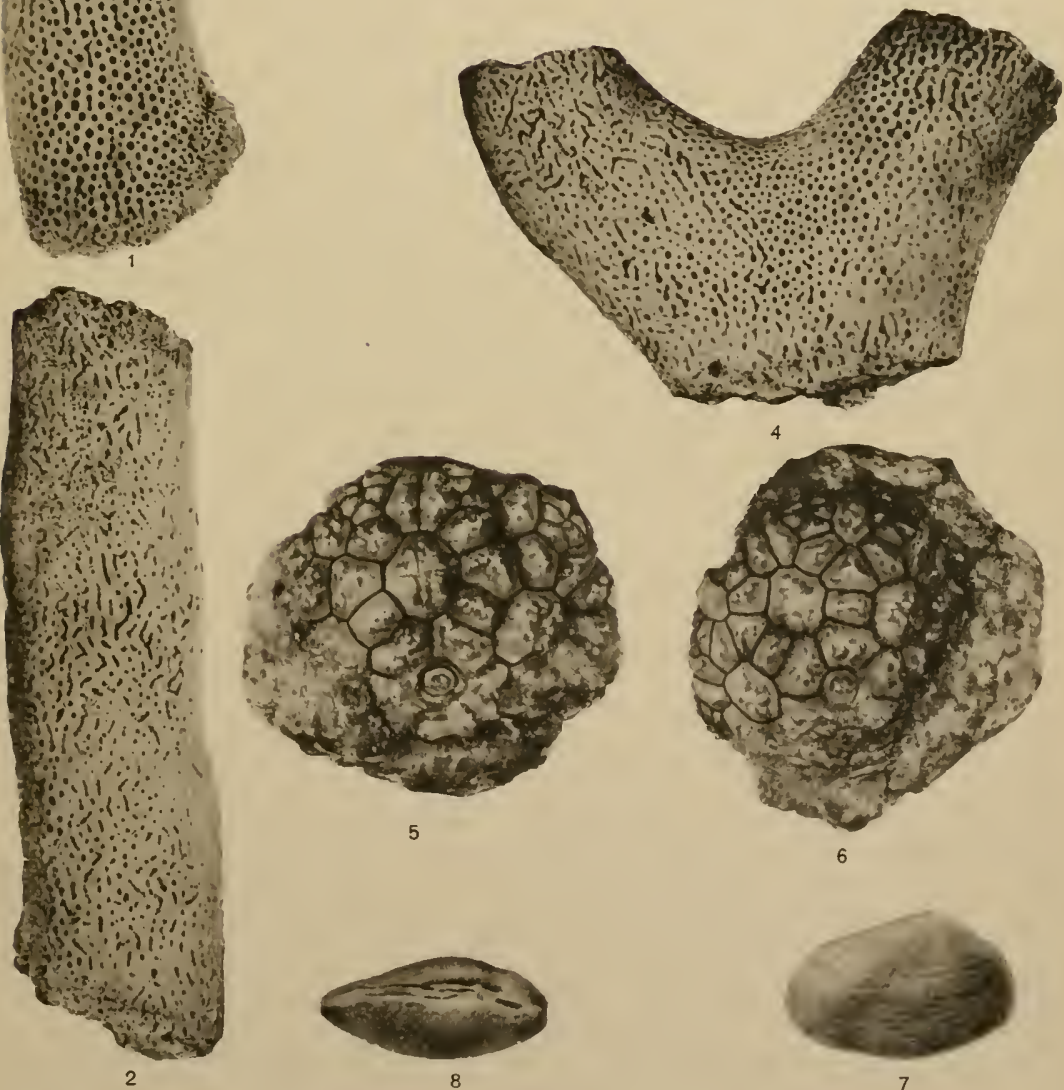


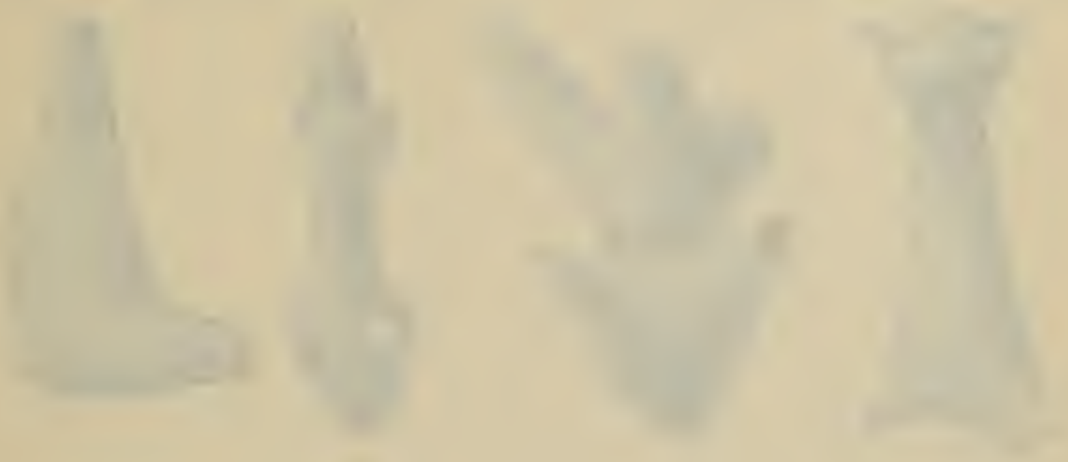

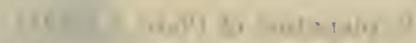

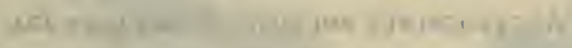

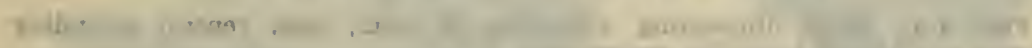
-

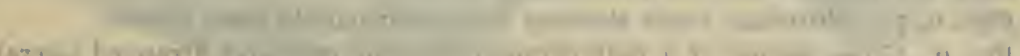

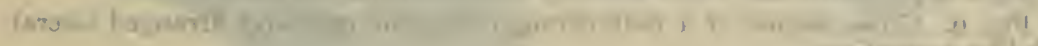
the

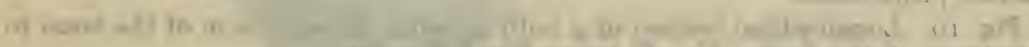

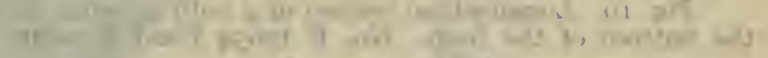

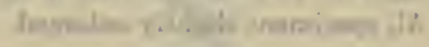

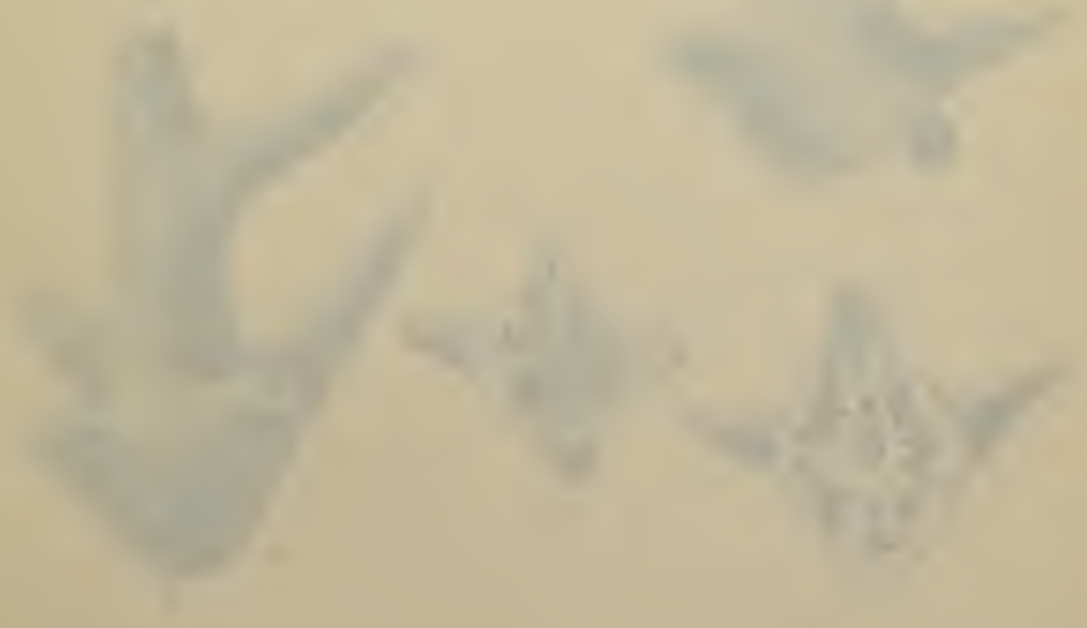


Explanation of Plate XXXIII

ANCYRocrinus bULbosUs Hall, page 204.

Figs. I-8. Series illustrating variations in form, size, central ascending processes and lateral hook-like projections.

Figs. 6, 7. Proximal views showing the quadripartite stem lumen.

Fig. 9. Cross section of a bulb through the four regularly arranged lateral hook-like projections.

Fig. I0. Longitudinal section of a bulb showing the extension of the stem to the bottom of the bulb. No. P 19654 Field Museum.

All specimens slightly enlarged. 

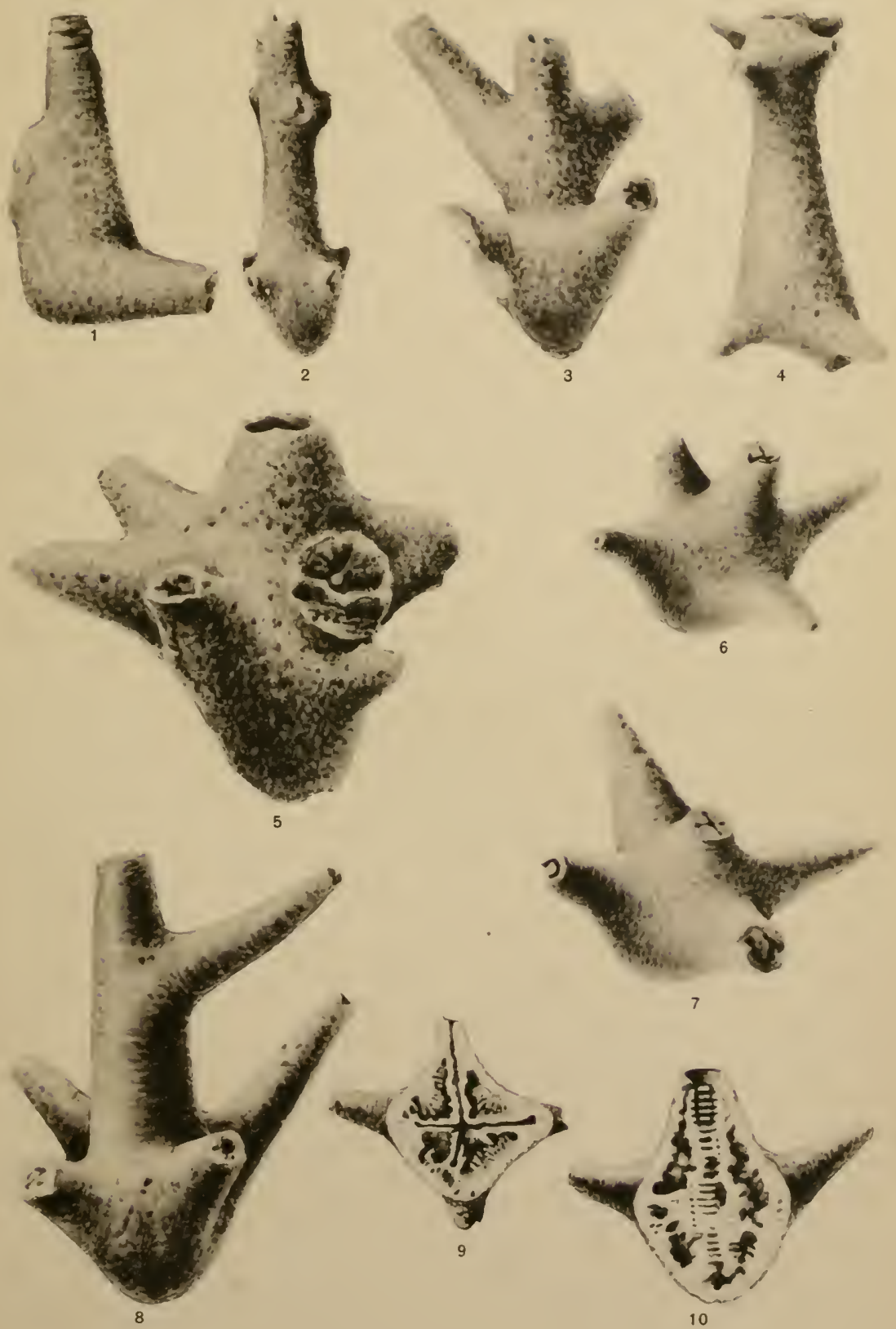




\section{Explanation of Plate XXXIV}

POTERIOCRINUS ROBBI sp. nov., page 205.

Figs. I,2. Anterior and posterior views. No. P 1986I Field Museum. Both figures slightly enlarged.

\section{Megalomus Canadensis Hall, page 207.}

Fig. 3. Anterior view of a cast showing the much depressed umbones.

Fig. 4. Lateral view of the same specimen. No. P 21716 Field Museum. Both figures slightly reduced. 





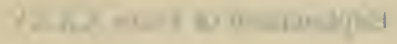

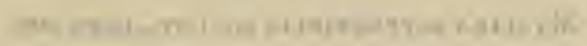

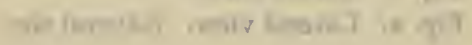

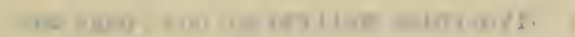

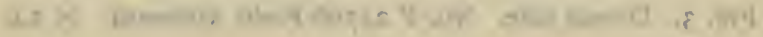

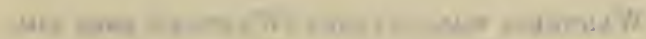

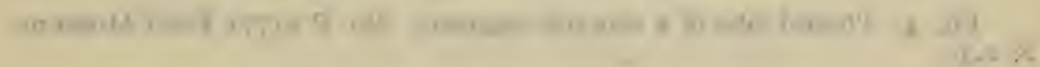

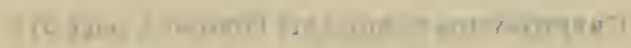

Lomm the

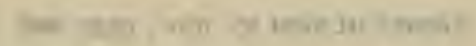

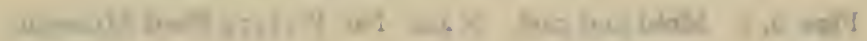




\section{Explanation of Plate XXXV}

Myalina SAPPEnFieldi sp. nov., page 206.

Fig. I. Dorsal view.

Fig. 2. Lateral view. Natural size.

Hyolithes WELLERI Sp. nov., page 208.

Fig. 3. Dorsal side. No. P 21766 Field Museum. $\times 2.6$

WANNERIA Walcottanus (WANNER), page 2 ro.

Fig. 4. Pleural lobe of a thoracic segment. No. P 2177 I Field Museum. $\times 2.3$.

Cryptonymus Variolaris (Brong.), page 211 .

Fig. 5. An entire specimen. No. P 2155r Field Museum. Slightly enlarged.

NIOBE? HUBERI sp. nov., page 208. 212

Figs. 6, 7. Mold and cast. $\times 2.2$. No. P 21775 Field Museum. 


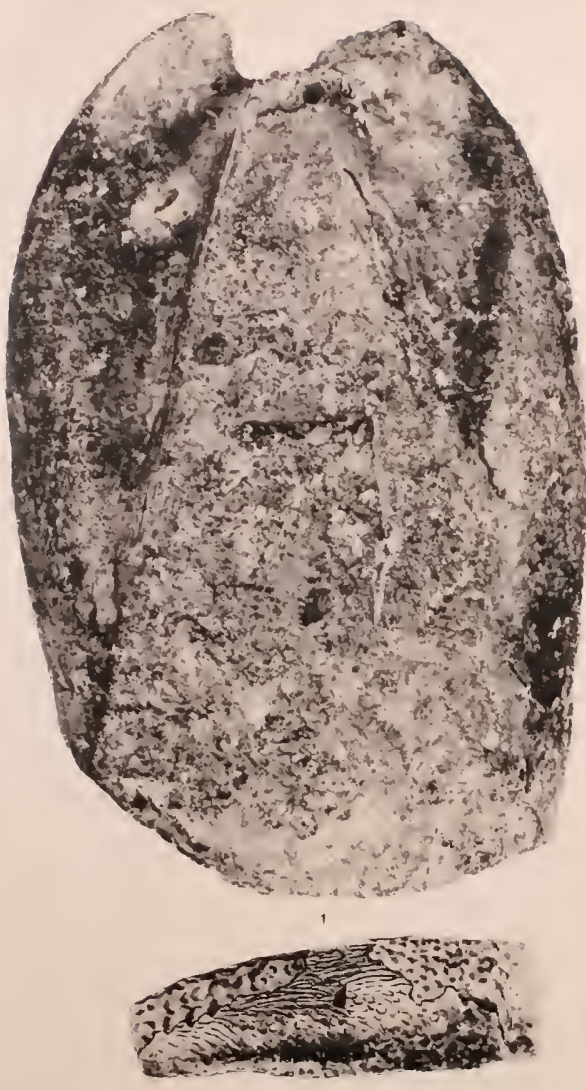
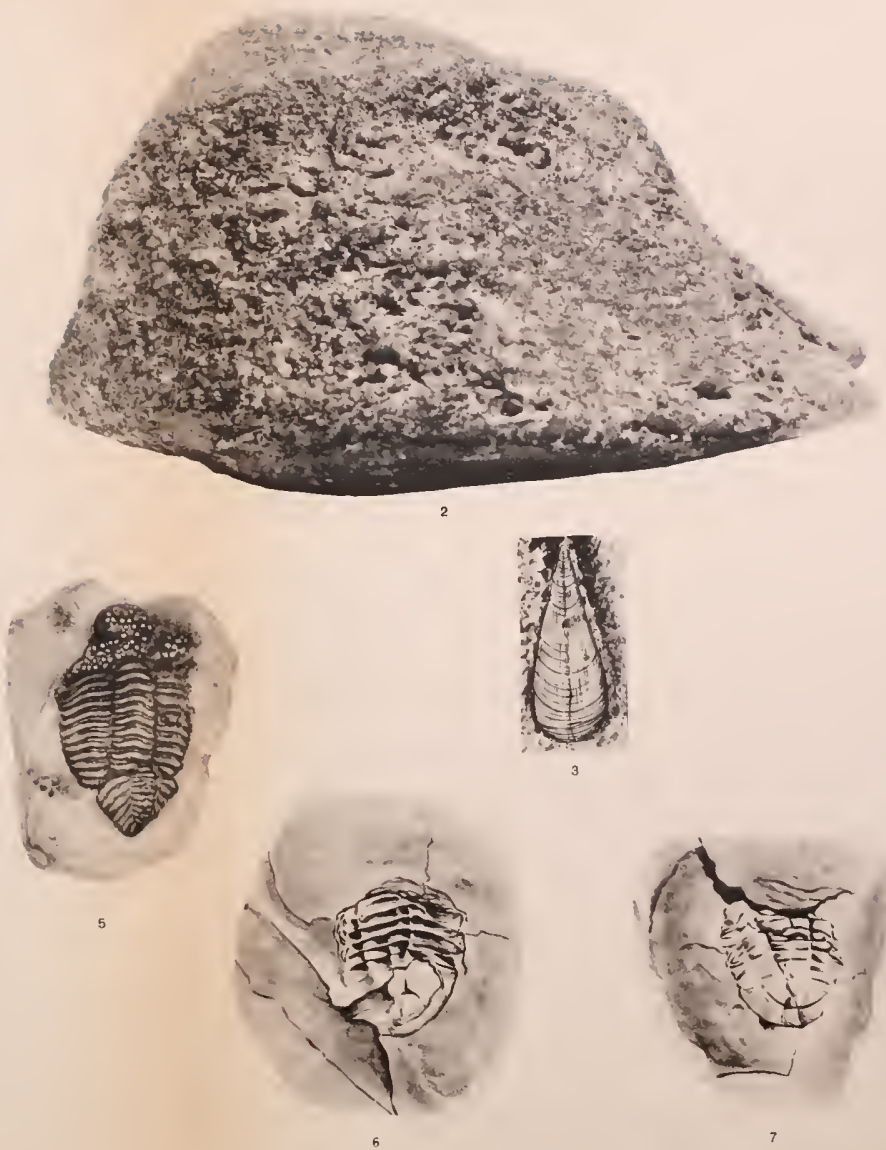


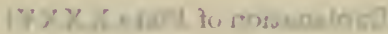

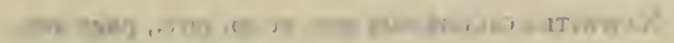

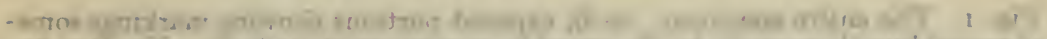

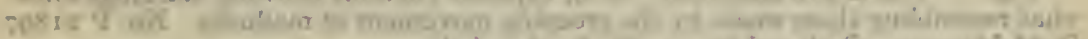

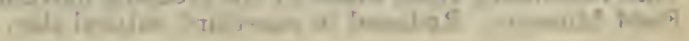




\section{Explanation of Plate XXXVI}

NaWNites GILboensis gen. et sp. nov., page 209.

Fig. I. The entire specimen. la-lb, exposed portions showing markings somewhat resembling those made by the creeping movement of mollusks. No. P 21897 Field Museum. Reduced to one-third natural size. 



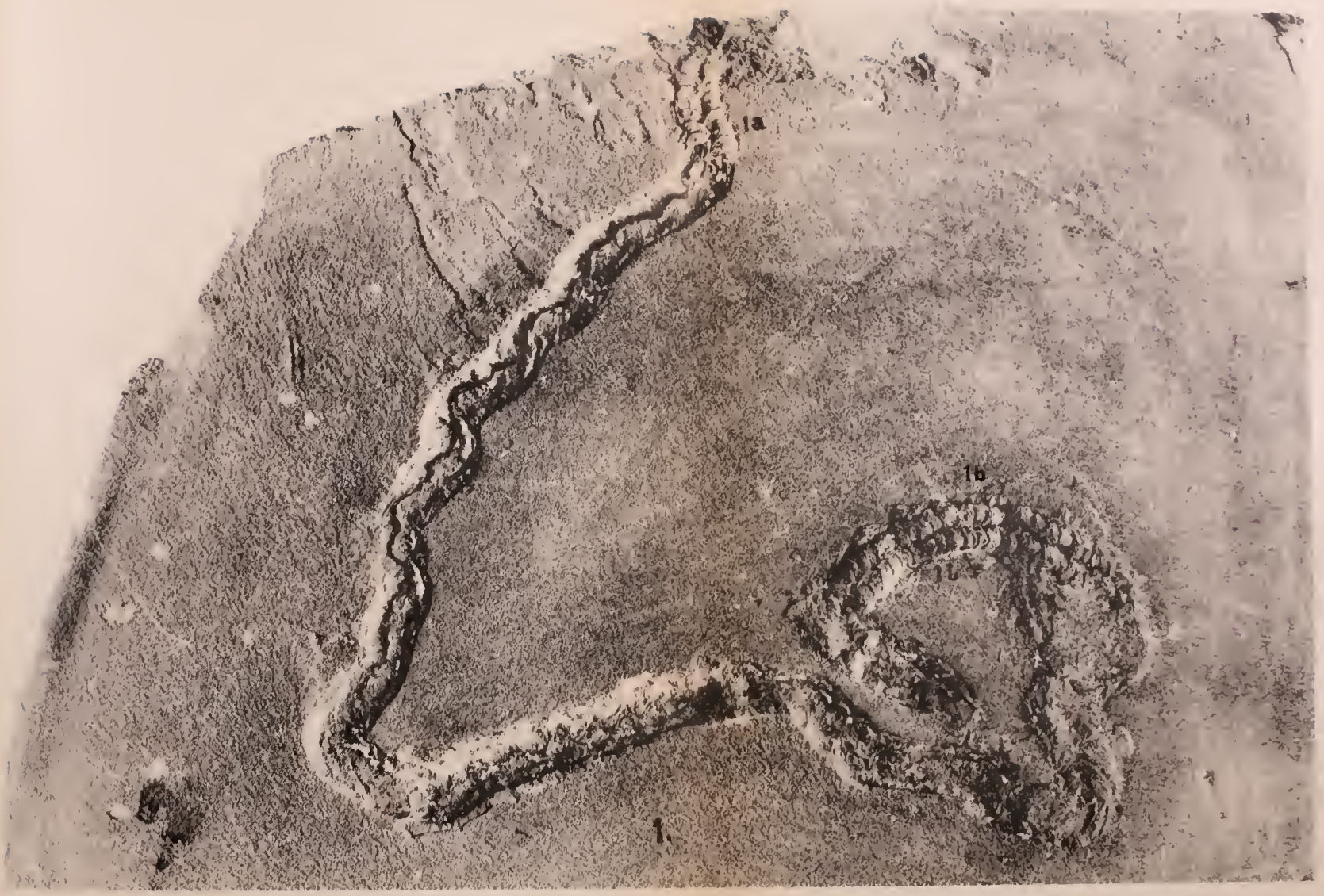




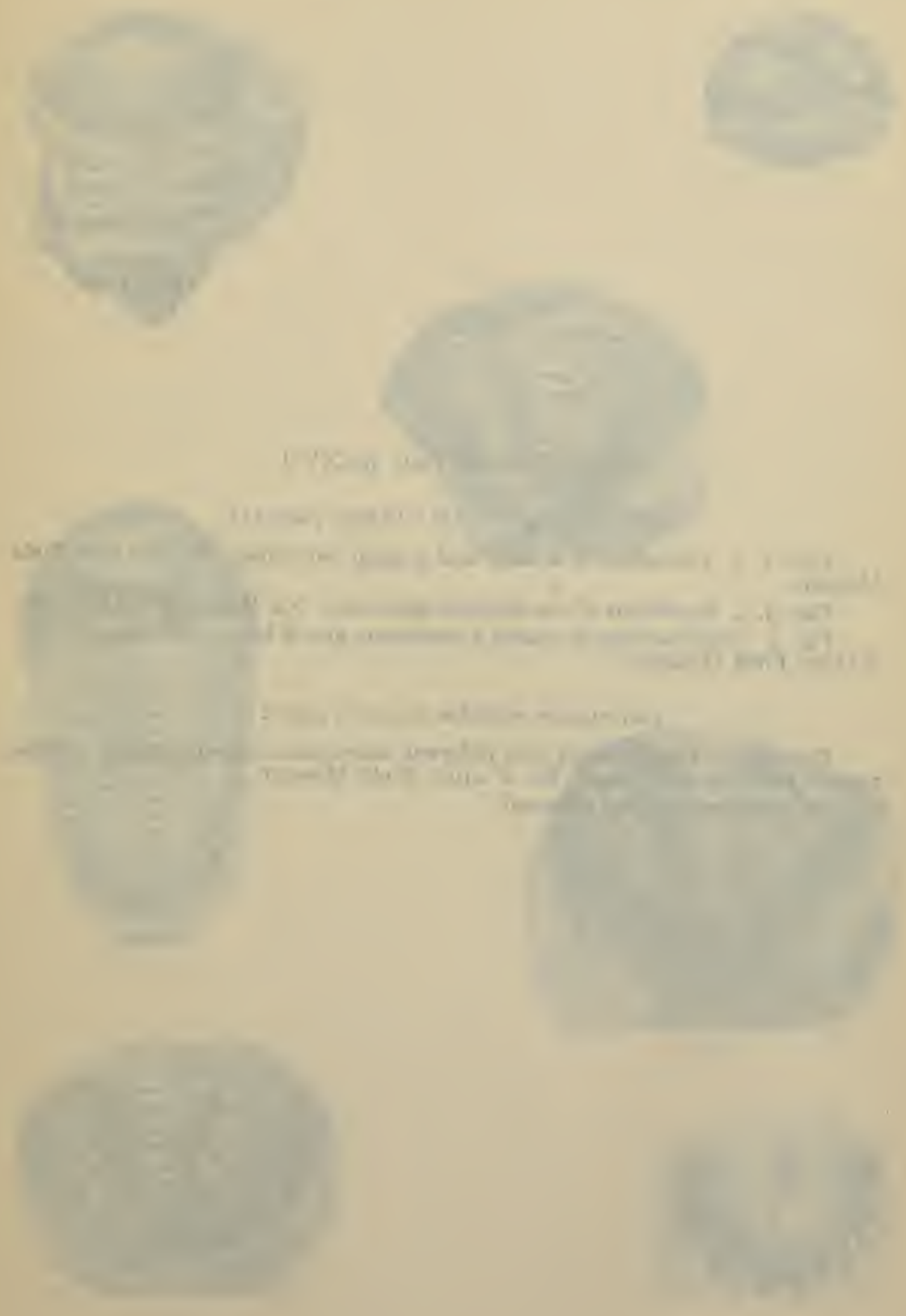


Cryphaeus australis Clarke, page 2 i3.

Figs. I, 2. Cephalons of a large and a small individual. No. P 2 Igoo Field Museum.

Figs. 3, 5. Pygidiums of two different specimens. No. P 21907 Field Museum. Fig. 4. This specimen is within a concretion and is but partly exposed. No. P 21900 Field Museum.

Cryphaeus nicholsi sp. nov., page 2 I 4 .

Figs. 6, 7. Pygidiums of two different individuals showing gently convex, rapidly tapering axial lobes. No. P 21906 Field Museum.

All specimens slightly enlarged. 

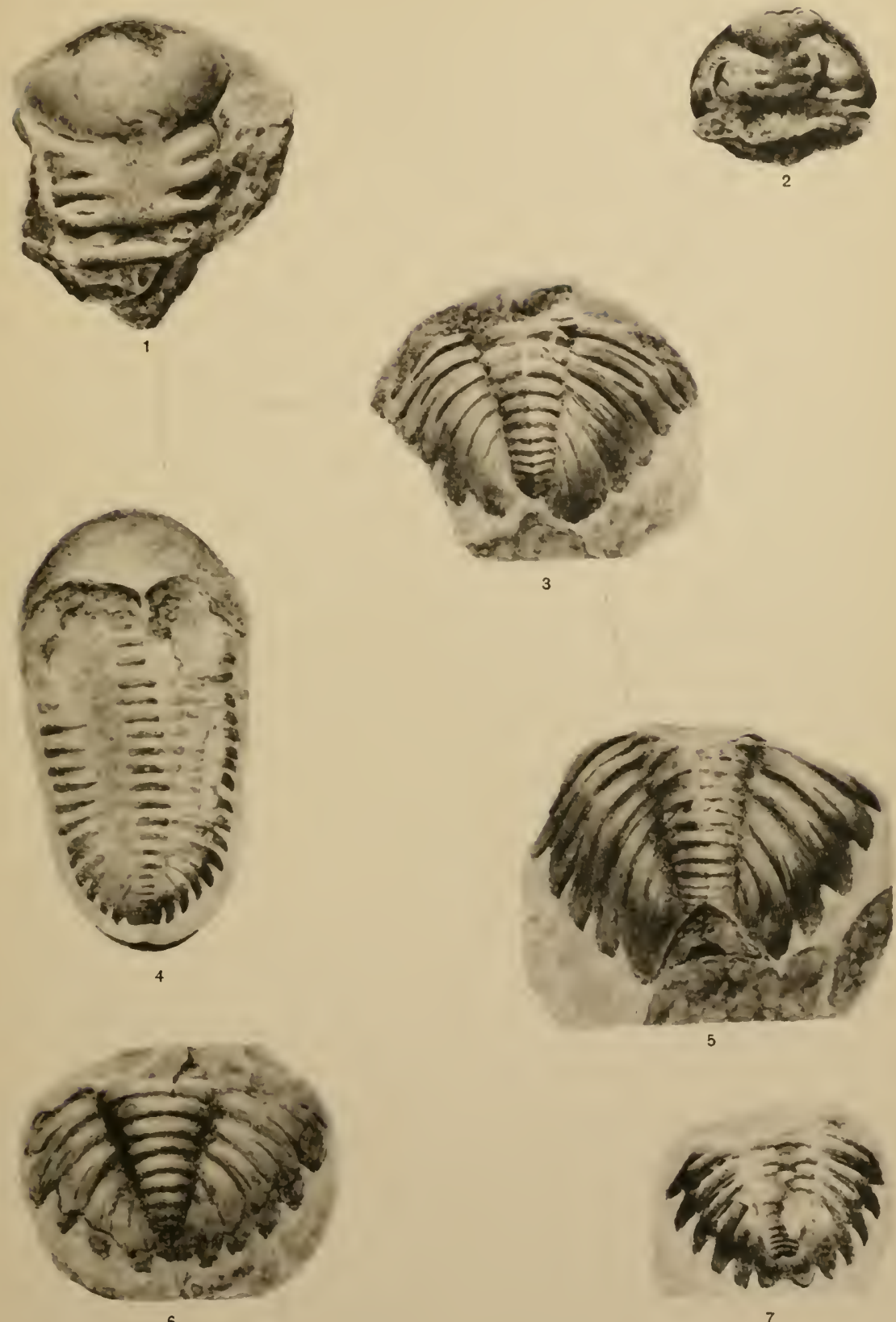


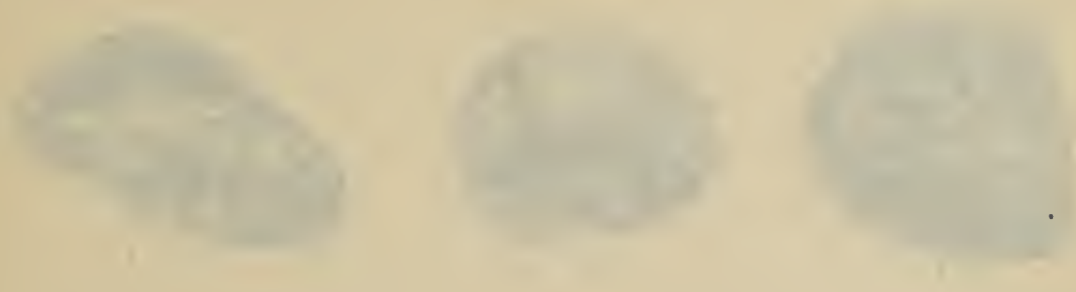

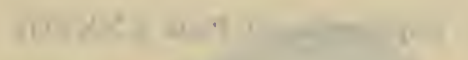

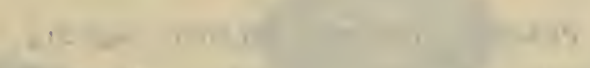

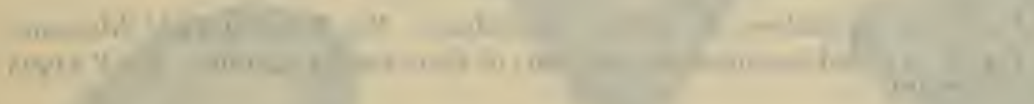

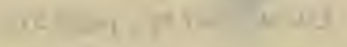

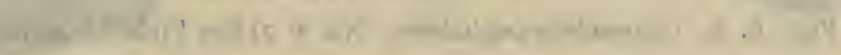

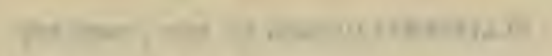

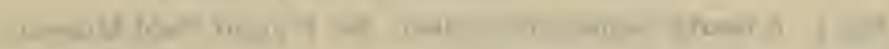

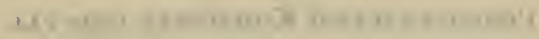
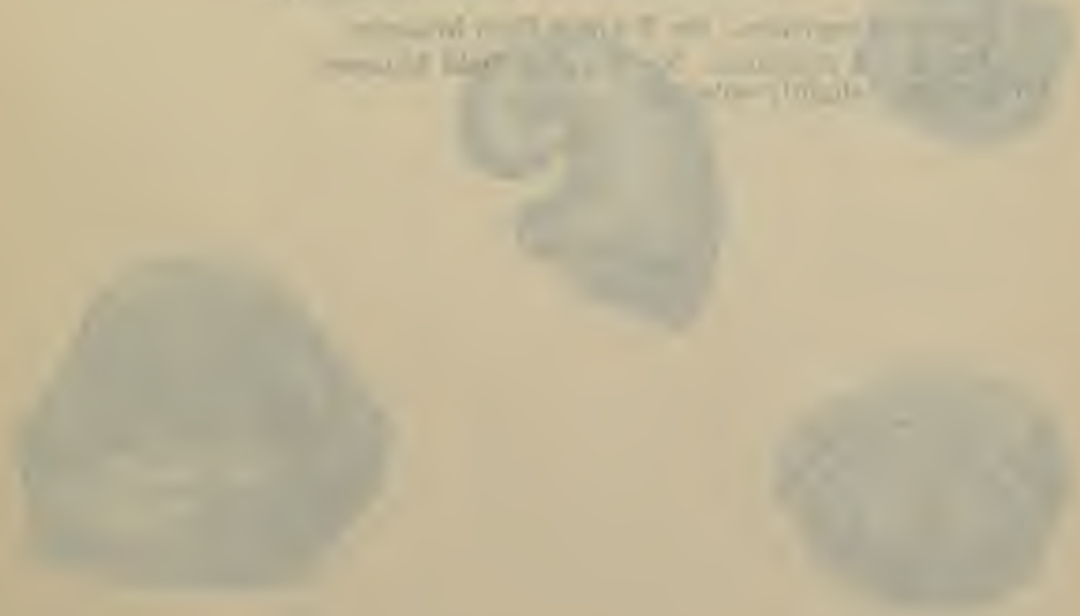
Explanation of Plate XXXVIII

Phacopina devonica (UlRich), page 214.

Figs. I-4. Cephalons of different individuals. No. P 21904 Field Museum.

Fig. 5. A coiled specimen showing pa1t of thorax and pygidium. No. P 21903 Field Museum.

$$
\text { Calmonia? sp., page } 2 r_{3} \text {. }
$$

Figs. 6, 8. Incomolete cephalons. No. P 21899 Field Museum.

Platyceras daviesi sp. nov., page 207.

Fig. 7. A nearly complete individual. No. P 21901 Field Museum.

Phacops Salteri Kozlowskr, page 2 I 4.

Fig. 9. A cephalon. No. P 21898 Field Museum.

Fig. I o. A pygidium. No. P 21898 Field Museum.

All specimens slightly enlarged 

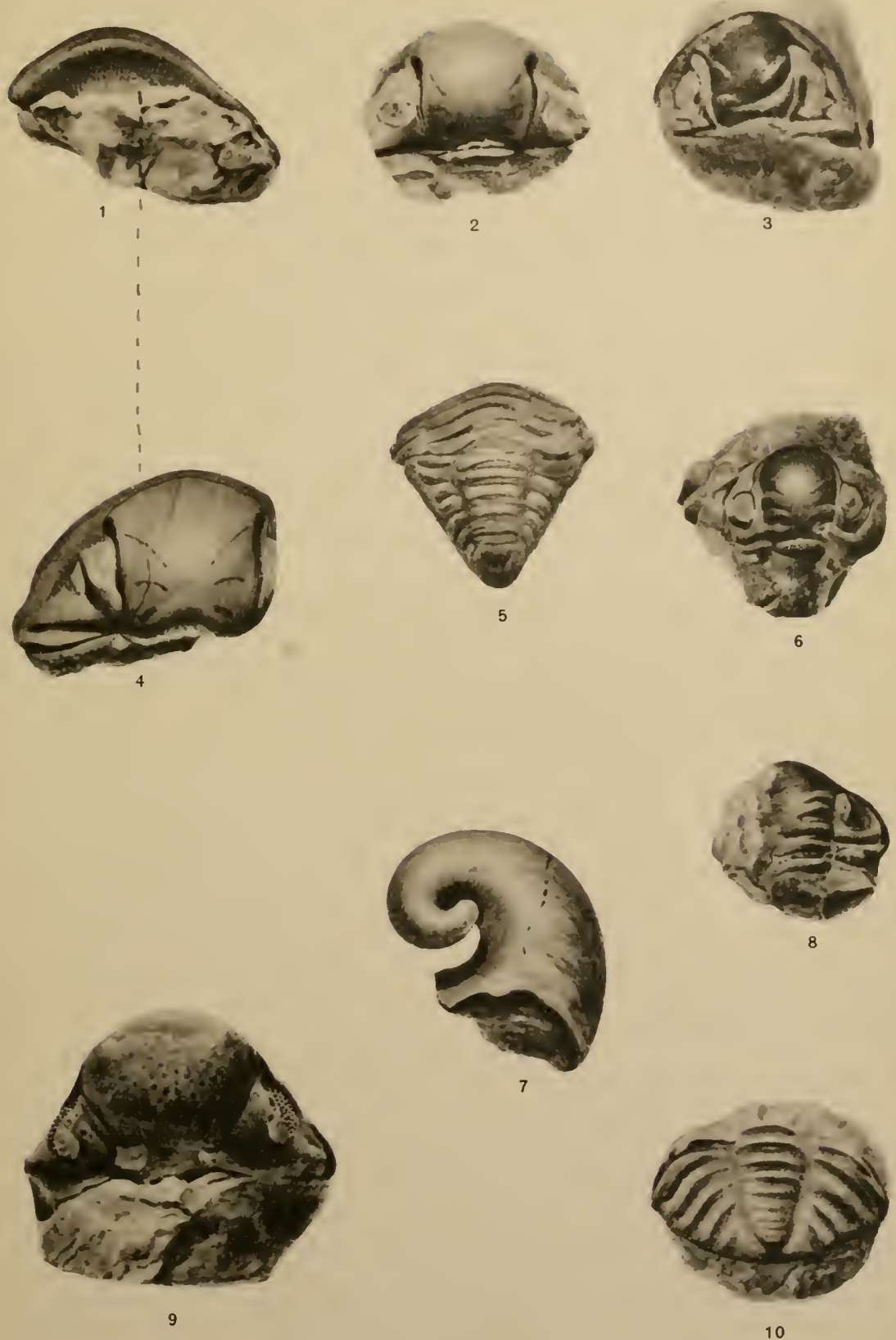



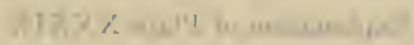

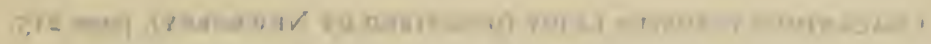

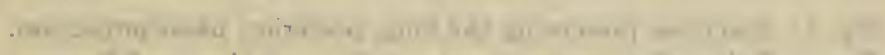

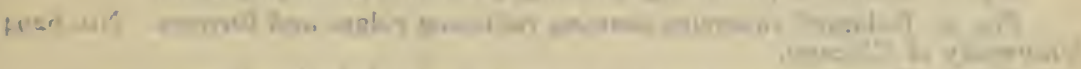

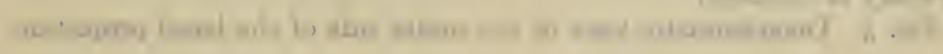

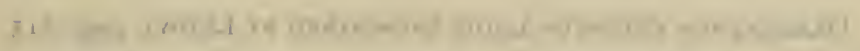

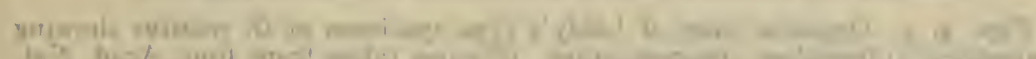

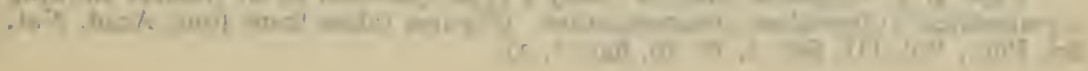

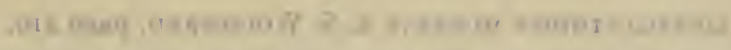

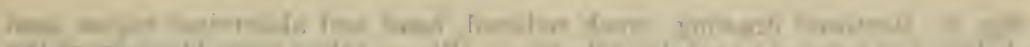

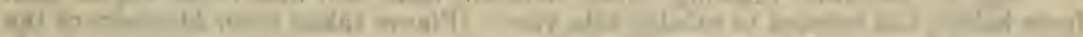
Whe con

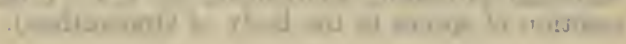




\section{Explanation of Plate XXXIX}

Oracanthus vetustus Leidy (Described by Newberry), page 2 i 5.

Fig. I. Specimen preserving the long, posterior, basal projection.

Fig. 2. Enlarged tubercles showing radiating ridges and furrows. No. 6294 University of Chicago.

Fig. 3. Diagrammatic view of the under side of the basal projection.

Oracanthus vetustus Leidy (DEscribed by Leidy), page 215.

Figs. 4, 5. Opposite sides of Leidy's type specimen of $O$. vetustus showing asymmetrical tuberculose ornamentation. (Figures taken from Jour. Acad. Nat. Sci. Phil., Vol. III, Ser. 2, Pl. I6, figs. I, 2).

Gyracanthides murrayi A. S. Woodward, page 216.

Fig. 6. Restored drawing, much reduced, head and abdominal region seen from below, tail twisted to exhibit side view. (Figure taken from Memoirs of the National Museum, Melbourne, No. I, P1. I, fig. I, I 906, to illustrate the probable position of spines in the body of Oracanthus). 



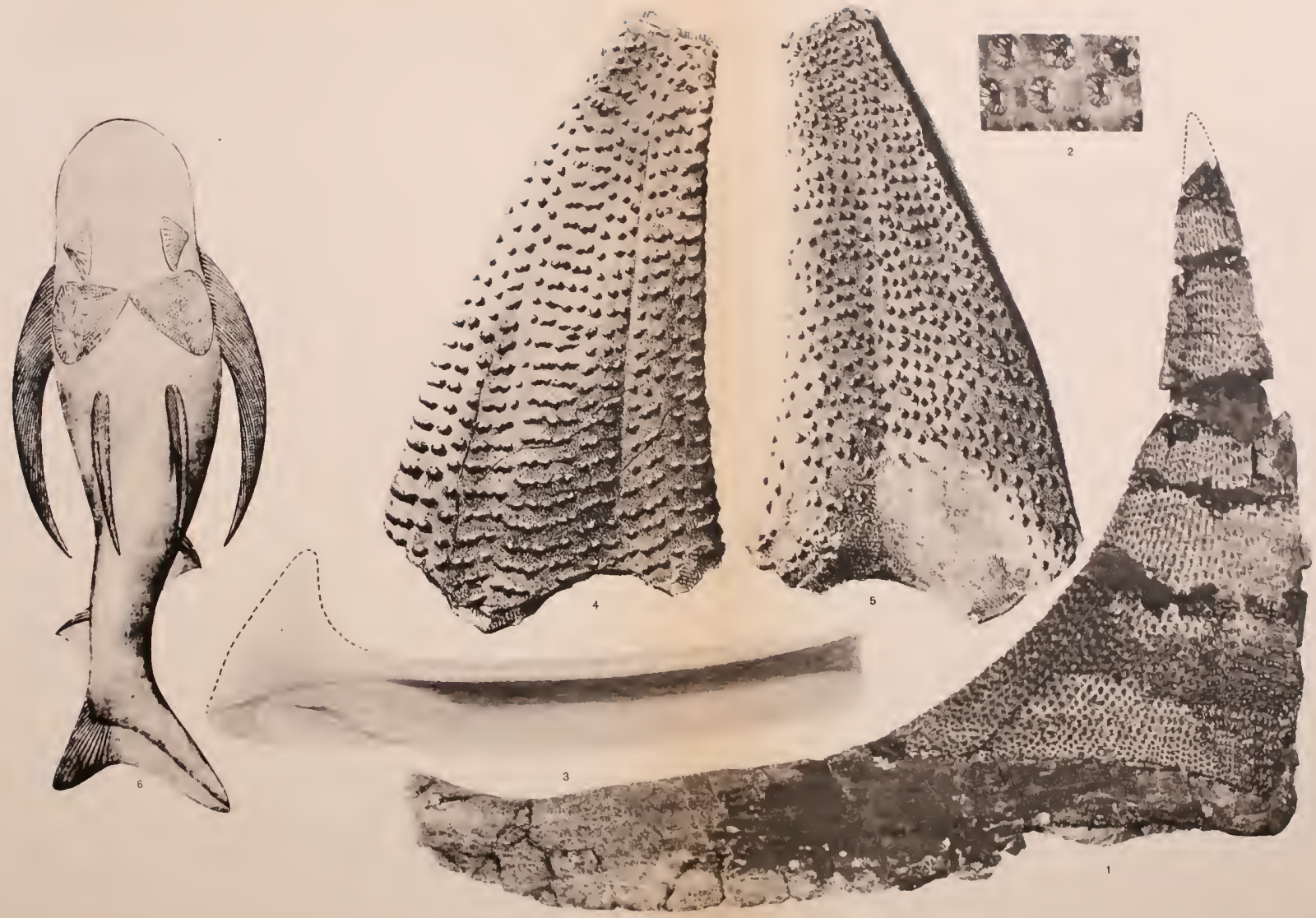




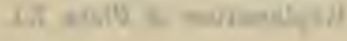

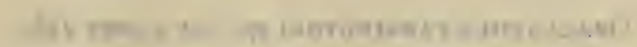

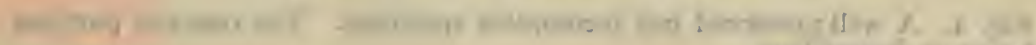
$\sin 1$ (

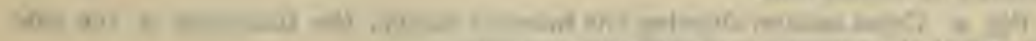
mo

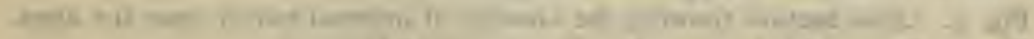

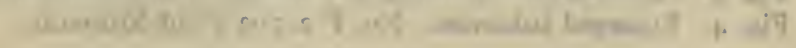

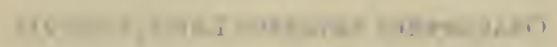

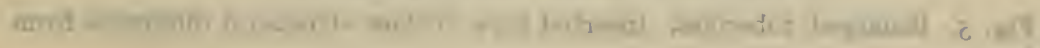




\section{Explanation of Plate XL}

ORACANTHUS FARRINGTONI sp. nov., page 218.

Fig. I. A well preserved but incomplete specimen. The restored portions are drawn in dotted line.

Fig. 2. Cross section showing the internal cavity, the thickness of the side walls and of the anterior and posterior margins.

Fig. 3. Cross section showing the absence of internal cavity near the apex.

Fig. 4. Enlarged tubercles. No. P 21702 Field Museum.

Oracanthus vetustus Leidy, page 215.

Fig. 5. Enlarged tubercles. Inserted here to show structural difference from fig. 4 . 


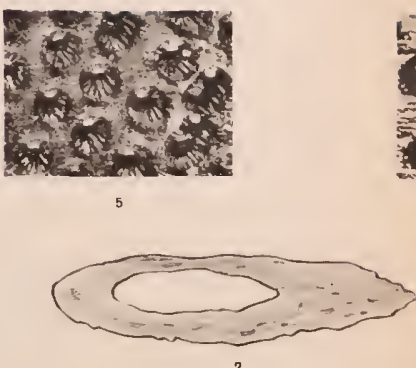

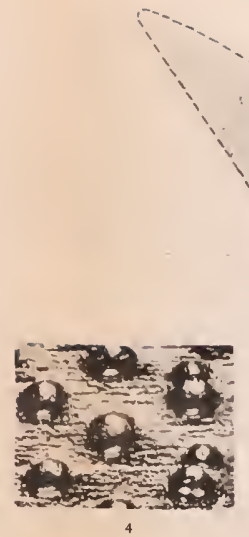

4

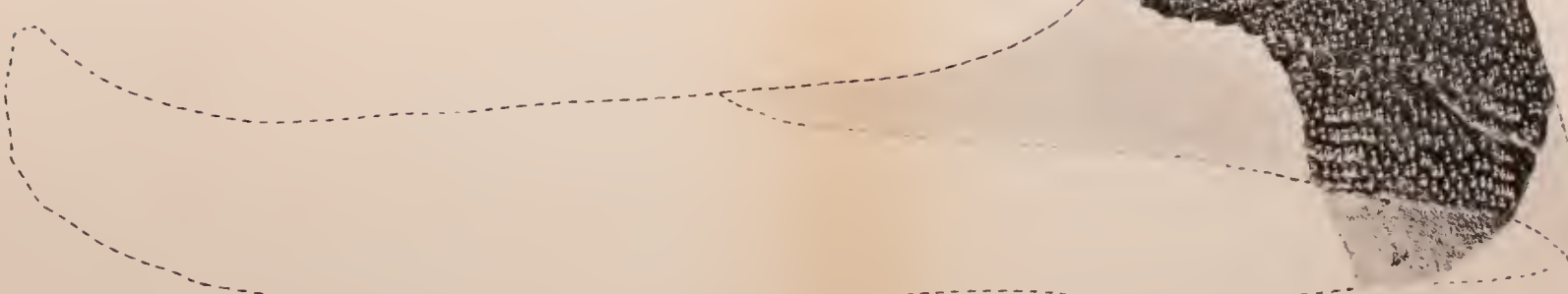



